\title{
A Consumers' Republic: The Politics of Mass Consumption in Postwar America
}

\section{Citation}

Cohen, Lizabeth. 2004. A consumers' republic: The politics of mass consumption in postwar America. Journal of Consumer Research 31(1): 236-239.

\section{Published Version}

doi:10.1086/383439

\section{Permanent link}

http://nrs.harvard.edu/urn-3:HUL.InstRepos:4699747

\section{Terms of Use}

This article was downloaded from Harvard University's DASH repository, and is made available under the terms and conditions applicable to Other Posted Material, as set forth at http:// nrs.harvard.edu/urn-3:HUL.InstRepos:dash.current.terms-of-use\#LAA

\section{Share Your Story}

The Harvard community has made this article openly available.

Please share how this access benefits you. Submit a story.

\section{Accessibility}




\title{
Reflections and Reviews
}

\section{A Consumers' Republic: The Politics of Mass Consumption in Postwar America}

\author{
LIZABETH COHEN*
}

$\mathrm{H}$

istorians and social scientists analyzing the contemporary world unfortunately have too little contact and hence miss some of the ways that their interests overlap and the research of one field might benefit another. I am, therefore, extremely grateful that the Journal of Consumer Research has invited me to share with its readers an overview of my recent research on the political and social impact of the flourishing of mass consumption on twentieth-century America. What follows is a summary of my major arguments, enough to entice you, I hope, to read A Consumers' Republic (Cohen 2003), in which I elaborate on these themes. Although this essay is by necessity schematic, the book itself is filled with extensive historical evidence and is heavily illustrated with period images. In tracing the growing importance of mass consumption to the American economy, polity, culture, and social landscape from the 1920s to the present, I in many ways establish the historical context for your research into contemporary consumer behavior and markets. I hope you will discover illuminating and fruitful connections between your work and my own.

The United States came out of World War II deeply determined to prolong and enhance the economic recovery brought on by the war, lest the crippling depression of the 1930 s return. Ensuring a prosperous peacetime would require making new kinds of products and selling them to different kinds of markets. Although military production would persist, and expand greatly with the cold war, its critical partner in delivering prosperity was the mass con-

\footnotetext{
*Lizabeth Cohen is the Howard Mumford Jones Professor of American Studies in the Department of History, Harvard University, Cambridge, MA 02138 (cohen3@fas.harvard.edu). She received her Ph.D. from the University of California, Berkeley, and has taught at Carnegie Mellon and New York universities. She is the author of Making a New Deal: Industrial Workers in Chicago, 1919-1939 (New York: Cambridge University Press, 1990), which won the Bancroft Prize and was a finalist of the Pulitzer, and most recently, A Consumers' Republic: The Politics of Mass Consumption in Postwar America, work on which was supported by fellowships from the Guggenheim Foundation, the American Association of Learned Societies, the National Endowment for the Humanities, and the Radcliffe Institute of Advanced Study.
}

sumer market. A wide range of economic interests and players all came to endorse the centrality of mass consumption to a successful reconversion from war to peace. Factory assembly lines newly renovated with Uncle Sam's dollars stood awaiting conversion from building tanks and munitions for battle to producing cars and appliances for sale to consumers.

If encouraging a mass consumer economy seemed to make good economic sense for the nation, it still required extensive efforts to get Americans to cooperate. Certainly, there was tremendous pent-up demand for goods, housing, and almost everything else after a decade and a half of wrenching depression and war, but consumers were cautious about spending the savings and war bonds that they had gladly accumulated while consumption was restricted on the home front. Hence, beginning during the war and with great fervor after it, business leaders, labor unions, government agencies, the mass media, advertisers, and many other purveyors of the new postwar order conveyed the message that mass consumption was not a personal indulgence. Rather, it was a civic responsibility designed to improve the living standards of all Americans, a critical part of a prosperityproducing cycle of expanded consumer demand fueling greater production, thereby creating more well-paying jobs and in turn more affluent consumers capable of stoking the economy with their purchases. As Bride's magazine told the acquisitive readers of its handbook for newlyweds, when you buy "the dozens of things you never bought or even thought of before . . . you are helping to build greater security for the industries of this country. . . . What you buy and how you buy it is very vital in your new life-and to our whole American way of living" (quoted in Harvey 1993, p. 110).

For its promoters, this mass-consumption-driven economy held out the promise of political as well as economic democracy. Reconversion after World War II raised the hopes of Americans of many political persuasions and social positions that not only a more prosperous but also a more equitable and democratic American society would finally be 
possible in the mid-twentieth century due to the enormous, and war-proven, capacities of mass production and mass consumption. As Americans lived better and on a more equal footing with their neighbors, it was expected, the dream of a more egalitarian America would finally be achieved. Politicians never tired of tying America's political and economic superiority over the Soviet Union to its more democratic distribution of goods.

The new postwar order deemed, then, that the good customer devoted to "more, newer, and better" was in fact the good citizen, responsible for making the United States a more desirable place for all its people. Wherever one looked in the aftermath of war, one found a vision of postwar America where the general good was best served not by frugality or even moderation, but by individuals pursuing personal wants in a flourishing mass consumption marketplace. Private consumption and public benefit, it was widely argued, went hand in hand. And what made this strategy all the more attractive was the way it promised a socially progressive end of social equality without requiring politically progressive means of redistributing existing wealth. Rather, it was argued, an ever-growing economy built around the twin dynamics of increased productivity and mass purchasing power would expand the overall pie without reducing the size of any of the portions.

What I have called the ideal of the Consumers' Republic - my phrase, not a label used at the time- - had far-reaching ramifications for the physical character of postwar America. To begin with, new house construction provided the bedrock of the postwar mass consumption economy, both through turning "home" into an expensive commodity for purchase by many more consumers than ever before and by stimulating demand for related commodities, such as cars, appliances, and furnishings. The scale of new residential construction following World War II was unprecedented. One out of every four homes standing in the United States in 1960 went up in the 1950s. As a result of this explosion in house construction, by the same year, $62 \%$ of Americans could claim that they owned their own homes, in contrast to only $44 \%$ as recently as 1940 (the biggest jump in home ownership rates ever recorded). And this explosion of the private real estate market was made possible by a mixed economy of private enterprise bolstered by government subsidy - in the form of mortgage guarantees with low interest rates and no down payment directly to buyers as part of the veterans benefits under the GI Bill of 1944, and indirectly to buyers through loan insurance to lenders and developers through the Federal Housing Administration. The federal government assisted as well through granting mortgage interest deductions on income taxes, a mass tax since World War II, and constructing highways from cities out to the farmland that overnight was being transformed into vast suburban tract developments.

The greater democracy and equality expected to accompany the flourishing of private real estate markets in the Consumers' Republic proved illusive, however. The passage of time revealed that certain kinds of metropolitan locales, as well as particular social groups, benefited over others. Dependence on new single-family, privately owned, detached home construction to solve the enormous postwar housing crunch as well as to fuel the economy privileged suburbs over cities. By 1965, a majority of Americans would make their homes in suburbs rather than cities.

The home ownership at the heart of the Consumers' Republic did more than expand the numbers and enhance the status of suburbanites over urbanites. Through their greater access to home mortgages, credit, and tax advantages, men benefited over women, whites over blacks, and middle-class Americans over working-class ones. Men, for example, secured low VA mortgages, and the additional credit that home ownership made available, as a result of their veteran status in World War II and the Korean War, while women generally did not. White Americans more easily qualified for mortgages, including those dispensed through the GI Bill, which worked through existing-and consistently discriminatory-banking institutions, and more readily found suburban houses to buy than African Americans could. And while some working-class Americans did move to suburbs, increasingly they tended to settle in "cops and firemen" suburban towns quite distinct from where successful professionals and entrepreneurs lived. A metropolitan landscape emerged where whole communities were increasingly being stratified along class and racial lines. As home, particularly a new one, in the Consumers' Republic became a commodity to be traded up, "property values" became the new mantra. Of course, people still chose the towns they lived in, but increasingly they selected among internally homogeneous suburban communities occupying different rungs in a hierarchy of property values. A community's racial profile contributed along with its house prices to positioning it on that ladder of prestige. Many suburban whites leaving cities with growing African American populations felt that only an all-white community would ensure the safety of their investment, often their entire life savings, and they did everything within their means to restrict blacks' access to real estate. As the neighbor of the first black family to move into Levittown, Pennsylvania, in 1957 told a Life magazine reporter, "He's probably a nice guy, but every time I look at him I see \$2000 drop off the value of my house" (Life 1957).

This increasing segmentation of suburbia by class and race fueled even more damaging social inequality because of Americans' traditional devotion to home rule as a critical pillar of democracy, a conviction that only intensified with suburbanization in the postwar period. As a result of postwar Americans' loyalty to localism, the quality of crucial services soon varied much more than they formerly had when more people lived within larger units of cross-class and interracial cities. Education, for example, widely recognized as the best ticket to success in postwar America, became captive to the inequalities of the new metropolitan landscape, since local communities substantially provided, and paid for, their own schools through local property taxes. The wealthier the community, the more it had to spend, and the greater prospect of its children receiving the kind of edu- 
cation that led to prestigious college and graduate degrees and well-paying jobs.

The stratification of the residential metropolis in postwar America was accompanied by a similar segmentation, as well as commercialization and privatization of public space, of what previously had been the urban downtown. By the mid-1950s, a new market structure-the regional shopping center-well-suited to this suburbanized, mass consumption-oriented society emerged, a vision and soon a reality where the center of community life was a site devoted to mass consumption, and what was promoted as public space was in fact privately owned and geared to maximizing profits. As developers and store owners set out to make the shopping center a more perfect downtown, they explicitly aimed to exclude from this community space unwanted social groups such as vagrants, racial minorities, political activists, and poor people. They did so through a combination of location, marketing, and policing.

Whereas at first developers had sought to legitimize the new shopping centers by arguing for their centrality to commerce and community, over time they discovered that those two commitments could be in conflict. When antiwar protesters or striking employees noisily took their causes to the mall, the rights of free speech and free assembly were not always good for business and could conflict with the rights of private property owners - the shopping centers - to control entry to their land. Beginning in the 1960s, American courts all the way up to the Supreme Court struggled with the political consequences of having moved public life off the street into the privately owned shopping center. The ultimate outcome was that the U.S. Supreme Court ruled that the First Amendment of the U.S. Constitution did not guarantee free access to shopping centers, and it was left to the states to decide whether or not their own constitutions did. Only in six states have state supreme courts protected citizens' rights in privately owned shopping centers, and even in some of those states activity has been limited.

The shopping centers of the 1950s and 1960s also contributed to a new calibration of consumer authority in the household between men and women that in many ways limited women's power over the family purse. For all the attention that shopping centers lavished on women, they did little to enhance their social and economic power. Rather, as mass consumption became more and more central to the health of the economy, shopping centers and the stores within them celebrated the family as a consumer unit and paid increasing attention to men as the chief breadwinner and consumer. Men's increased involvement in family purchasing was also reinforced by the huge expansion of credit that shopping centers encouraged, making credit cards and other forms of credit the legal tender of mall purchasing. Until the passage of equal credit legislation in the 1970s, the growing importance of credit deepened men's oversight of their wives and daughters, as male names and credit ratings were required for women's own access. Finally, shopping centers put limits on women's independence as workers, not just consumers, as suburban stores came to depend on hiring part-time female sales help living nearby, to whom they offered low pay and few benefits. Not only did suburban housewives offer cheap and flexible labor, but their hiring helped branch department stores undermine the retail clerks unions that had successfully organized the flagship stores downtown.

The economic and social stratification of metropolitan America was reinforced by marketers and advertisers, who simultaneously discovered the greater profits to be made in segmenting the market into distinctive submarkets based on gender, class, age, race, ethnicity, and lifestyle. The Consumers' Republic was founded in the 1940s and 1950s on the conviction that mass markets offered endless potential for growth and appealed to all Americans. "The rich man smokes the same sort of cigarettes as the poor man, shaves with the same sort of razor, uses the same sort of telephone, vacuum cleaner, radio and TV set," and drives a car with only minor variations, Harper's Magazine typically asserted (quotation by Professor H. Gordon Hayes [1947], cited in Allen 1952, p. 193). But by the late 1950s, advertisers, marketers, and manufacturers began to worry that mass markets would soon be saturated as more and more Americans bought a house, car, refrigerator, and washing machine. The alternative that emerged, and flourished by the 1960s, was market segmentation, the division of mass markets into smaller market segments defined by distinctive orientations and tastes, each to be sold different products, or if the same product, to be sold in a totally different way. As segmenting pioneer Pierre Martineau argued in a groundbreaking article in the Journal of Marketing in 1958, a member of a market segment defined by social class or other criteria is "profoundly different in his mode of thinking and his way of handling the world. . . . Where he buys and what he buys will differ not only by economics but in symbolic value" (Martineau 1958, pp. 122-23).

When market segmentation exacerbated the divisions between social groups, it reinforced the fragmentation created by residential communities and commercial centers. And when politicians and campaign managers began to apply the techniques of market segmentation to the political sphere beginning in the 1960s, the shift from mass to segment took on larger political significance. Politicians targeted voters with distinctive messages aimed at their political interests narrowly construed, and voters, much like the segmented buyers of goods who sought the best match for their distinctive tastes and desires with what was available in the commercial marketplace, similarly came to expect the political marketplace - consisting of candidates, government agencies, and PACS - to respond to their particular needs and interests. In multiple arenas, then, Americans were propelled away from the common ground of the mass toward the divided, and often unequal, territories of population fragments, in the process accentuating everything that made them different from each other and undermining any broadbased political agenda designed to serve the public good.

The application of market segmentation to politics beginning in the 1960s and increasing thereafter was part of 
a larger tendency in the Consumers' Republic to let the techniques and standards of the private marketplace define success in more and more spheres of American life. As the test of value increasingly became market viability, even the notion of public government itself became at risk. During the last half century, Americans' confidence that an economy and culture built around mass consumption could best deliver greater democracy and equality led us from the Consumers' Republic to what I call the "consumerization of the republic." Americans increasingly came to judge the success of the public realm much like other purchased goods, by the personal benefit individual citizen-consumers derived from it.

I do acknowledge in this book that the linkage made in the Consumers' Republic between citizen and consumer spawned some important grassroots, democratic political action, most notably the civil rights movement that began as a drive for access to public_-often commercialaccommodations in the North right after World War II. If citizens had a patriotic responsibility to consume, then denying them was a violation of both a free market and a free society, it was argued. And I also explore how the democratic expectations raised by the Consumers' Republic fueled the impressive consumer movement of the 1960s and 1970s, as citizen consumers aimed to hold corporations and government to higher moral and quality standards. But by the beginning of the twenty-first century, more often than not Americans are asking of the public domain, "Am I getting my money's worth?" rather than "What's best for America?" Knowingly or not, they speak in an idiom that evolved out of the perhaps initially naive but ultimately misguided conviction of the Consumers' Republic that private markets could solve the nation's social and political as well as economic problems, somehow delivering greater democracy and prosperity to one and all at the very same time.

[Dawn Iacobucci served as editor for this article.]

\section{REFERENCES}

Allen, Frederick Lewis (1952), The Big Change: America Transforms Itself, 1900-1950, New York: Harper \& Bros.

Cohen, Lizabeth (2003), A Consumers' Republic: The Politics of Mass Consumption in Postwar America, New York: Knopf.

Harvey, Brett (1993), The Fifties: A Women's Oral History, New York: HarperCollins.

Life (1957), "Integration Troubles Beset Northern Town," September $2,43-46$.

Martineau, Pierre (1958), "Social Classes and Spending Behavior," Journal of Marketing, 23 (October), 121-30. 